Asian Australas. J. Biosci. Biotechnol. 2020, 5 (1), 33-41

Asian-Australasian Journal of

Bioscience and Biotechnology

ISSN 2414-1283 (Print) 2414-6293 (Online)

www.ebupress.com/journal/aajbb

\title{
Article \\ Frozen semen quality and fertility of imported pure Holstein Friesian and Sahiwal breeding bulls in Bangladesh
}

\author{
Md Mehedi Hasan ${ }^{1,2}$, Md Rafikul Islam ${ }^{1}$, Syed Sakhawat Husain ${ }^{1 *}$ and Auvijit Saha $\mathrm{Apu}^{1}$ \\ ${ }^{1}$ Department of Animal Breeding and Genetics, Bangladesh Agricultural University, Mymensingh-2202, \\ Bangladesh \\ ${ }^{2}$ Department of livestock Services, Dhaka, Bangladesh
}

*Corresponding author: Professor Dr. Syed Sakhawat Husain, Department of Animal Breeding and Genetics, Bangladesh Agricultural University, Mymensingh-2202, Bangladesh. E-mail: sshusain53@gmail.com

Received: 01 April 2020/Accepted: 28 April 2020/ Published: 30 April 2020

\begin{abstract}
The present study was conducted to evaluate the frozen semen quality in terms of different motility patterns and fertility of imported pure Holstein Friesian and Sahiwal breeding bulls maintained under farming condition of Bangladesh. 100\% pure Holstein Friesian and Sahiwal breeding bulls were imported and thereafter reared in the American dairy limited (ADL). Semen samples were collected once a week, processed and frozen in the laboratory of ADL. On the day of collection, semen volume and sperm concentration measured immediately after collection. Different motility patterns of spermatozoa (progressive, fast, slow, local, immotile) were measured by Computer Assisted Semen Analyzer (CASA). Effect of breed was found significant ( $<0.05)$ on semen volume and sperm concentration. The semen volume (ml/ejaculate) and sperm concentration $\left(\times 10^{6}\right)$ were found to be $6.13 \pm 0.28$ and $1664.28 \pm 62.41$ in Holstein Friesian breeding bulls whereas $5.26 \pm 0.17$ and $2036.00 \pm 43.99$ in Sahiwal bulls, respectively. The progressive motility, fast motility, slow motility and local motility were significantly $(\mathrm{p}<0.05)$ higher in Holstein Friesian bulls than that of Sahiwal bulls both before and after freezing. Different motility patterns such as progressive, fast, slow, local and immotile motility were found to be $89.22 \pm 0.45 \%, 75.97 \pm 0.67 \%, 9.10 \pm 0.36 \%, 4.25 \pm 0.15 \%$ and $10.05 \pm 0.41 \%$ in Holstein Friesian bulls whereas $84.98 \pm 0.89 \%, 65.99 \pm 0.92 \%, 11.88 \pm 0.37 \%, 5.65 \pm 0.19 \%$ and $15.69 \pm 0.54 \%$ in Sahiwal breeding bulls, respectively before freezing. On the other hand, after freezing, the progressive, fast, slow, local and immotile spermatozoa were found to be $68.19 \pm 0.46 \%, 53.39 \pm 2.01 \%, 9.21 \pm 0.46 \%, 8.47 \pm 0.72 \%$ and $26.76 \pm 2.01 \%$ in Holstein Friesian bulls whereas $56.54 \pm 0.25 \%, 42.52 \pm 0.67 \%, 11.11 \pm 0.55 \%, 13.04 \pm 1.24 \%$ and $30.45 \pm 1.58 \%$ in Sahiwal bulls, respectively. Non-return rate was found insignificant between the breeds and it was $64.19 \%$ in Holstein Friesian and $64.71 \%$ in Sahiwal bulls. In conclusion, frozen semen quality of Holstein Friesian pure breed is better than that of Sahiwal breeding bulls but fertility of both breeds are similar. Therefore, frozen semen of both breeds can be used in the field level for the genetic improvement of cattle.
\end{abstract}

Keywords: breed; frozen semen; motility; non-return rate

\section{Introduction}

Cattle population in Bangladesh encompasses mostly non-descript types with a few varieties namely Red Chittagong, Pabna, Munshiganj, and North Bengal grey cattle (Hossain et al., 2006). They are smaller in size and their milk production capacity is much lower.

The basic aim of cattle breeding program in Bangladesh is to improve the genetic potentiality of local cattle through infusion of exotic gene (Ahmed and Islam, 1987). There are two mating system practiced in our country such as natural and artificial. Having multiple benefits of Artificial Insemination (AI) over natural mating, it is getting popularity in our country. AI is the most economical and management tool as it provides the opportunity to spread the superior germplasm by the extensive use of progeny tested selected sires. On an average, a bull can 
produce fifty thousand progeny per year through AI compared to 40-50 progeny through natural mating (Salisbury et al., 1978). Hafez (1993) pointed out that Artificial insemination is the most important single technique ever devised for the rapid genetic improvement of animals. AI plays an important role to increase the yielding capacity of cows and is the appropriate and cheapest way of genetic improvement of cows.

Male selection is very much crucial in case of breeding. The biological and economic importance of a bull's contribution through natural breeding or artificial insemination (AI) for improving reproductive efficiency and production of meat or milk, or both is of great importance because each bull or its semen represents half of the genetic composition of its progeny (Foote, 1979). Male can serve many females with single ejaculation using artificial insemination and produce many offspring. Bull selection must be accurate otherwise the whole system will be collapsed. Any wrong decisions in bull selection can haphazard the whole system. For the economic viability, caution about poor quality bulls in terms semen quality should be taken into consideration. If there is problem in fertility due to fault of bulls, it will cause huge economic loss to the farmer. When only highly fertile bulls are used, better fertility are achieved, which reduces the costs of reproductive programs (Sudano et al., 2011).

Evaluation of semen parameter is a good indicator for judging the bull's reproductive performance. The term 'quality of semen' means package of parameters that represent the inner picture of semen related to fertility. Different factors including the type of extender, interactions between cryoprotectants, cooling rate, thawing rate and the physiological status of animals are important for successful semen cryopreservation and AI. Moreover, preservation process can also affect the quality and fertility. Semen preservation might be for either short tome (chilled) or long time (frozen). Frozen semen is replacing chilled semen and used all over the world due to some limitations of using chilled semen at the remote areas and for long time. On the other hand, in case of frozen semen, semen quality may deteriorate after freezing. So, it is necessary to ensure the semen quality in terms of different semen parameter after freezing.

In Bangladesh, a substantial number of crossbreds have been produced so far using the exotic gene pool of 50\% blood level of Holstein-Friesian, Sahiwal, Sindhi, Jersey breeding bulls. However, to make a white revolution in the country and meet up the huge demand of milk and milk products, pure Holstein Friesian and Sahiwal breeding bulls have been imported in Bangladesh by different private organizations and entrepreneurs. Their aim is to disseminate the genetic merit of these pure breeding bulls though frozen semen and genetic improvement of our cattle. But no research works have been performed before to evaluate these breeding bulls and their frozen quality and fertility in the context of Bangladesh. From this point of view, our aim is to evaluate the frozen semen quality and fertility of these imported pure Holstein Friesian and Sahiwal breeding bulls maintained in the farming condition of Bangladesh.

\section{Materials and Methods}

\subsection{Selection of breeding bulls}

$100 \%$ Holstein Friesian (HF) and Sahiwal (SW) pure breeding bulls have been imported and maintained in American dairy Limited, Vagnahati, Sreepur, Gazipur. Among them, three Holstein Friesian and three Sahiwal breeding bulls were selected on the basis of age, body weight and scrotal circumference (SC) and used for this research. The ages of these breeding bulls ranged from 4 to 6 years, body weight from 1048 to $1134 \mathrm{~kg}$ and scrotal circumference from 34 to $37 \mathrm{~cm}$ for HF bulls. In case of SW bulls, age ranged from 4 to 5 years, body weight 600 to $645 \mathrm{~kg}$ and SC was 34.5 to $37.0 \mathrm{~cm}$, respectively. Bulls were maintained in intensive farming condition and supplied with balanced ration comprising concentrate and roughage depending on their body weight. Fresh water was made available all the time.

\subsection{Preparation of diluter}

Egg yolk-citrate (EYC) diluter was prepared at previous night of collection of semen. It was a solution of $2.94 \%$ sodium citrate in $100 \mathrm{ml}$ of distilled water and in which $100000 \mathrm{IU}$ of penicillin and $100000 \mu \mathrm{g}$ of streptomycin were added. One parts of egg by volume was added with three parts of the sodium citrate solution. It was stored in proper temperature and used after overnight preservation.

\subsection{Semen collection and evaluation of fresh and diluted semen}

Semen was collected by means of artificial vagina (AV) method once in a week. Ejaculate volume was measured using graduated collection vial tube in milliliter. The concentration of spermatozoa was determined by Density Spectrophotometer (SDM-6, Minitübe, Germany). Fresh semen was diluted in cuvettes with 0.9\% sodium chloride solution at the ratio of 1:100. The reading was recorded from the Density Spectrophotometer in million/ml. After that fresh semen was diluted with prepared EYC diluter. Progressive motility, fast motility, 
slow motility, local motility and immotility of diluted semen were measured by using Computer Assisted Semen Analysis (CASA) system (Andro Vision AX10, Minitübe, Germany).

\subsection{Processing for frozen semen production}

Diluted semen was filled with automatic filling, sealing and printing machine (MPP Quattro, Minitube, Germany) that could fill 4 straws at a time. For equilibration, semen straws were decorated in the racks and placed in the cold handling cabinets named cooling castle maintained at $4-5^{\circ} \mathrm{c}$ for 3-4 hours. Semen straw was transferred from cold handling cabinets to Bio freezer (TurboFreezer L, Minitube, Germany). After keeping in the chamber of device, temperature was controlled by programmable software. Temperature curves and data of each freezing cycle could be stored, displayed and transferred into excel for further analysis. Subsequent freezing cycles started immediately after the previous freezing. The unidirectional nitrogen gas flow in the freezer ensured that all straws passed through identical freezing curves. After freezing one (1) or two (2) straw were taken per batch and analyzed to know the status of progressive, fast, slow, local motility and immotility of the spermatozoa by using CASA system and then transferred to large cryocan maintained at $-196^{\circ} \mathrm{c}$ for preservation.

\subsection{Artificial insemination and fertility measurement}

Artificial insemination (AI) was performed in different areas of Mymensingh districts using the frozen-thawed semen of pure Holstein Friesian and Sahiwal breeding bulls. Bull fertility was measured in terms of Non-return rate (NRR). NRR was recorded by the percentage of cows that were not returned to estrus at 60 days after AI and calculated in percentage using the following formula.

Non-return rate $(\%)=\frac{\text { Cows not returned to estrus within } 60 \text { days }}{\text { Total number of cows inseminated }} \times 100$

\subsection{Statistical analysis}

The data obtained from the experiment were entered in Microsoft Excel worksheet, organized and processed for further analysis. Analysis was performed with the help of Statistical Analysis System (SAS, 2009) computer package.

\section{Results}

\subsection{Evaluation of fresh semen}

Means along with standard error (SE) of volume and sperm concentration of the experimental breeding bulls are shown in Table 1. Semen volume of Holstein Friesian $(6.13 \pm 0.28 \mathrm{ml})$ was significantly $(\mathrm{p}<0.05)$ higher than that of Sahiwal breeding bull $(5.26 \pm 0.17 \mathrm{ml})$. The number of spermatozoa per $\mathrm{ml}$ semen of Sahiwal bull $\left(2036.53 \pm 43.99 \times 10^{6}\right)$ was significantly $(\mathrm{p}<0.05)$ higher than that of Holstein Friesian $\left(1664.28 \pm 62.41 \times 10^{6}\right)$ bull.

\subsection{Evaluation of diluted semen}

Different motility patterns of diluted semen in Holstein Friesian and Sahiwal bulls are presented in Table 2. The mean progressive motility of Holstein Friesian bull semen $(89.22 \pm 0.45 \%)$ was significantly $(\mathrm{p}<0.05)$ higher than that of semen of Sahiwal bull $(84.98 \pm 0.89 \%)$. The same scenario was observed for fast motility $(75.97 \pm 0.67 \%$ vs $65 \pm 0.99 \%, \mathrm{p}<0.01)$ in the diluted semen of these breeding bulls. On the other hand, slow motility, local motility and immotility percentage of Sahiwal bull semen $(11.88 \pm 0.37 \%, 5.65 \pm 0.19 \%$ and $15.69 \pm 0.54 \%)$ was significantly $(\mathrm{p}<0.05)$ higher than that of Holstein Friesian bull $(9.10 \pm 0.36 \%, 4.25 \pm 0.15 \%$ and $10.05 \pm 0.41 \%)$ respectively.

\subsection{Evaluation of frozen semen}

Table 3 showed that progressive and fast motility of frozen semen in Holstein Friesian bulls $(68.19 \pm 0.46 \%$ and $53.39 \pm 2.01 \%)$ was significantly higher $(p<0.01)$ than that of Sahiwal bulls $(56.54 \pm 0.25 \%$ and $42.52 \pm 0.67 \%)$, respectively. However, in case of slow motility and local motility of frozen semen of Sahiwal bull $(11.11 \pm 0.55 \%$ and $13.04 \pm 1.24 \%)$ was significantly $(\mathrm{p}<0.05)$ higher than that of semen of Holstein Friesian bull $(9.21 \pm 0.46 \%$ and $8.47 \pm 0.72 \%)$, respectively. Moreover, percentages of immotile spermatozoa in the frozen semen of Sahiwal bull (30.45 \pm 1.58$)$ were not significantly different than that of Holstein Friesian (26.76 \pm 2.01$)$ breeding bulls. 
3.4. Comparison of pre- and post-freezing motility pattern of spermatozoa

3.4.1. Progressive motility

The progressive motility ranged from $88-89 \%$ in pre-freezing diluted semen which decreased significantly $(\mathrm{p}<0.05)$ in the post-freezing evaluated semen $(60$ to $71 \%)$ in different pure Holstein Friesian breeding bulls (Figure 1). Similarly, freezing had a significant effect $(\mathrm{p}<0.05)$ on the progressive motility of Pure Sahiwal bull semen. Before freezing, the progressive motility of Sahiwal bull's semen ranged from 83 to $87 \%$ whereas after freezing, this percentage ranged from to 54 to $58 \%$ (Figure 1).

\subsubsection{Fast motility}

Figure 2 showed that the fast motility of different pure Holstein Friesian breeding bull's semen ranged from 75$77 \%$ before freezing and it declined significantly $(\mathrm{p}<0.05)$ with a range of $42-68 \%$ after freezing. Similar trend was also observed in the fast motility of Sahiwal bull semen where pre-freezing fast motility of different Sahiwal bull semen ranged from 62-69\% and post-freezing 40-45\% (Figure 2).

\subsubsection{Fertility of breeding bulls}

Fertility of breeding bulls was expressed based on the cows not returned to estrus within the next 60 days after insemination. The average non-return rate did not vary significantly between these two breeds and it was 64.19\% in Holstein Friesian and 64.71\% in Sahiwal bulls (Figure 3).

Table 1. Evaluation of fresh semen of pure Holstein Friesian and Sahiwal breeding bulls.

\begin{tabular}{llll}
\hline Breed & Bull ID. & Volume $(\mathbf{m l})(\mathbf{n = 1 2})$ & Concentration $\left(\times \mathbf{1 0}^{\mathbf{6}}\right)(\mathbf{n}=\mathbf{1 2})$ \\
\hline Holstein Friesian & 38 & $7.00 \pm 0.35$ & $1297.42 \pm 29.05$ \\
& 3577 & $4.29 \pm 0.24$ & $2036.25 \pm 36.93$ \\
& 3157 & $7.13 \pm 0.27$ & $1659.24 \pm 100.79$ \\
Pooled & & $\mathbf{6 . 1 3} \pm \mathbf{0 . 2 8}$ & $\mathbf{1 6 6 4 . 2 8} \pm \mathbf{6 2 . 4 1 ^ { \mathbf { b } }}$ \\
Sahiwal & 75 & $5.41 \pm 0.25$ & $2081.92 \pm 58.73$ \\
& 71 & $4.67 \pm 0.31$ & $2037.83 \pm 111.12$ \\
& 38708 & $5.70 \pm 0.71$ & $1989.83 \pm 47.82$ \\
Pooled & & $\mathbf{5 . 2 6} \pm \mathbf{0 . 1 7}$ & $\mathbf{2 0 3 6 . 5 3} \pm \mathbf{4 3 . 9 9 ^ { \mathbf { a } }}$ \\
Level of significance & & $* *$ & $* *$ \\
\hline
\end{tabular}

** $\mathrm{p}<0.01 ; \mathrm{NS}=$ Non-significant; $\mathrm{n}=$ Number of observation

Table 2. Evaluation of pre-freezing diluted semen of pure Holstein Friesian and Sahiwal bulls.

\begin{tabular}{|c|c|c|c|c|c|c|}
\hline Breed & Bull ID. & $\begin{array}{l}\text { PM (\%) } \\
(n=12)\end{array}$ & $\begin{array}{l}\text { FM }(\%) \\
(n=12)\end{array}$ & $\begin{array}{l}\mathrm{SM}(\%) \\
(\mathrm{n}=12)\end{array}$ & $\begin{array}{l}\text { LM (\%) } \\
(n=12)\end{array}$ & $\begin{array}{l}\operatorname{IMM}(\%) \\
(\mathrm{n}=12)\end{array}$ \\
\hline Holstein & 38 & $89.35 \pm 0.81$ & $77.55 \pm 1.21$ & $7.94 \pm 0.66$ & $4.07 \pm 0.22$ & $10.01 \pm 0.64$ \\
\hline \multirow[t]{2}{*}{ Friesian } & 3577 & $89.86 \pm 0.97$ & $75.20 \pm 0.93$ & $9.63 \pm 0.55$ & $4.12 \pm 0.25$ & $10.30 \pm 0.72$ \\
\hline & 3157 & $88.45 \pm 0.49$ & $75.15 \pm 1.29$ & $9.72 \pm 0.59$ & $4.56 \pm 028$ & $9.83 \pm 0.80$ \\
\hline Pooled & & $89.22 \pm 0.45^{\mathrm{a}}$ & $75.97 \pm 0.67^{\mathrm{a}}$ & $9.10 \pm 0.36^{b}$ & $4.25 \pm 0.15^{b}$ & $10.05 \pm 0.41^{\mathrm{a}}$ \\
\hline \multirow[t]{3}{*}{ Sahiwal } & 75 & $83.89 \pm 1.55$ & $66.31 \pm 1.04$ & $11.83 \pm 0.31$ & $5.57 \pm 0.36$ & $15.73 \pm 0.60$ \\
\hline & 71 & $83.49 \pm 1.46$ & $62.57 \pm 1.01$ & $12.80 \pm 0.46$ & $6.18 \pm 0.29$ & $17.11 \pm 0.59$ \\
\hline & 38708 & $87.54 \pm 1.46$ & $69.30 \pm 1.04$ & $10.98 \pm 0.94$ & $5.23 \pm 0.31$ & $14.23 \pm 1.29$ \\
\hline Pooled & & $84.98 \pm 0.89^{b}$ & $65.99 \pm 0.92^{b}$ & $11.88 \pm 0.37^{\mathrm{a}}$ & $5.65 \pm 0.19^{\mathrm{a}}$ & $15.69 \pm 0.54^{b}$ \\
\hline Level of & ance & $*$ & $* *$ & $*$ & $*$ & $* *$ \\
\hline
\end{tabular}

$* \mathrm{p}<0.05$; ** $\mathrm{p}<0.01$; Means with different superscripts within the same column of pooled value differ significantly between breeds $(\mathrm{p}<0.05)$;

$\mathrm{n}=$ Number of observation; PM=Progressive motility; FM=Fast motility; SM=Slow motility; LM=Local motility; IMM=Immotile. 
Table 3. Evaluation of frozen-thawed semen of pure Holstein Friesian and Sahiwal breeding bulls.

\begin{tabular}{|c|c|c|c|c|c|c|}
\hline Breed & ID. No. & $\begin{array}{l}\text { PM (\%) } \\
(n=12)\end{array}$ & $\begin{array}{l}\text { FM (\%) } \\
(\mathbf{n}=12)\end{array}$ & $\begin{array}{l}\text { SM (\%) } \\
(n=12)\end{array}$ & $\begin{array}{l}\operatorname{LM}(\%) \\
(n=12)\end{array}$ & $\begin{array}{l}\text { IMM (\%) } \\
(\mathrm{n}=12)\end{array}$ \\
\hline Holstein & 38 & $70.12 \pm 0.49$ & $68.00 \pm 1.44$ & $8.68 \pm 0.44$ & $7.80 \pm 083$ & $13.37 \pm 0.71$ \\
\hline \multirow[t]{2}{*}{ Friesian } & 3577 & $63.45 \pm 0.31$ & $42.47 \pm 2.09$ & $9.88 \pm 1.00$ & $6.44 \pm 0.44$ & $38.87 \pm 1.92$ \\
\hline & 3157 & $71.01 \pm 0.49$ & $49.69 \pm 1.25$ & $9.07 \pm 0.90$ & $11.18 \pm 1.75$ & $28.07 \pm 2.14$ \\
\hline Pooled & & $68.19 \pm 0.46^{\mathrm{a}}$ & $53.39 \pm 2.01^{\mathrm{a}}$ & $9.21 \pm 0.46^{b}$ & $8.47 \pm 0.72^{b}$ & $26.76 \pm 2.01^{\mathrm{a}}$ \\
\hline \multirow[t]{3}{*}{ Sahiwal } & 75 & $57.13 \pm 0.11$ & $42.99 \pm 0.76$ & $10.05 \pm 0.77$ & $13.89 \pm 2.00$ & $29.32 \pm 2.64$ \\
\hline & 71 & $54.28 \pm 0.41$ & $40.05 \pm 0.64$ & $12.41 \pm 1.04$ & $8.07 \pm 1.12$ & $37.46 \pm 1.67$ \\
\hline & 38708 & $58.28 \pm 0.23$ & $44.56 \pm 1.55$ & $10.87 \pm 0.88$ & $17.17 \pm 2.38$ & $24.58 \pm 2.38$ \\
\hline Pooled & & $56.54 \pm 0.25^{b}$ & $42.52 \pm 0.67^{b}$ & $11.11 \pm 0.55^{a}$ & $13.04 \pm 1.24^{\mathrm{a}}$ & $30.45 \pm 1.58^{\mathrm{a}}$ \\
\hline Level of & ance & $* *$ & $* *$ & * & $* *$ & NS \\
\hline
\end{tabular}

$* \mathrm{p}<0.05 ; * * \mathrm{p}<0.01 ; \mathrm{NS}=$ Not- significant; Means with different superscripts within the same column of pooled value differ significantly between breeds $(\mathrm{p}<0.05) ; \mathrm{n}=$ Number of observation; $\mathrm{PM=Progressive}$ motility; FM=Fast motility; $\mathrm{SM}=$ Slow motility; LM=Local motility; IMM=Immotile.
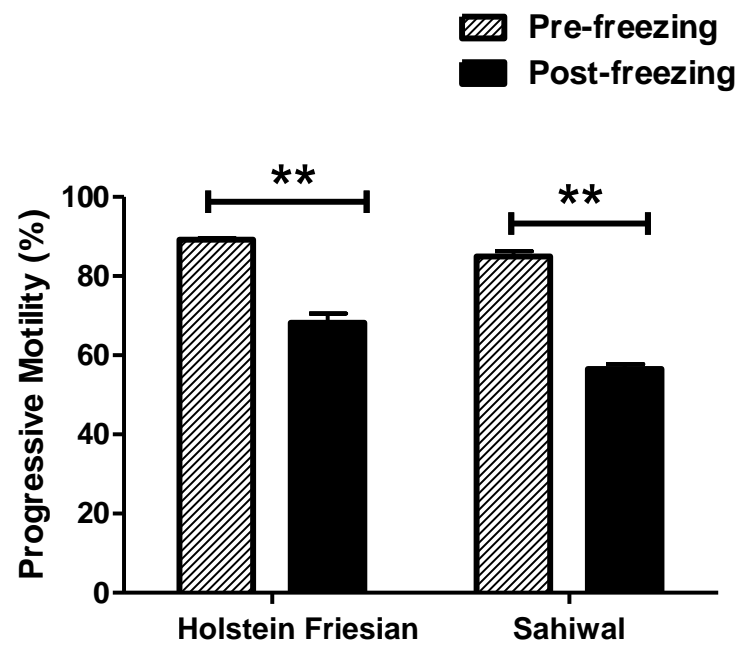

Figure 1. Comparison of pre- and post-freezing progressive motility of spermatozoa in pure Holstein Friesian and Sahiwal breeding bull semen.

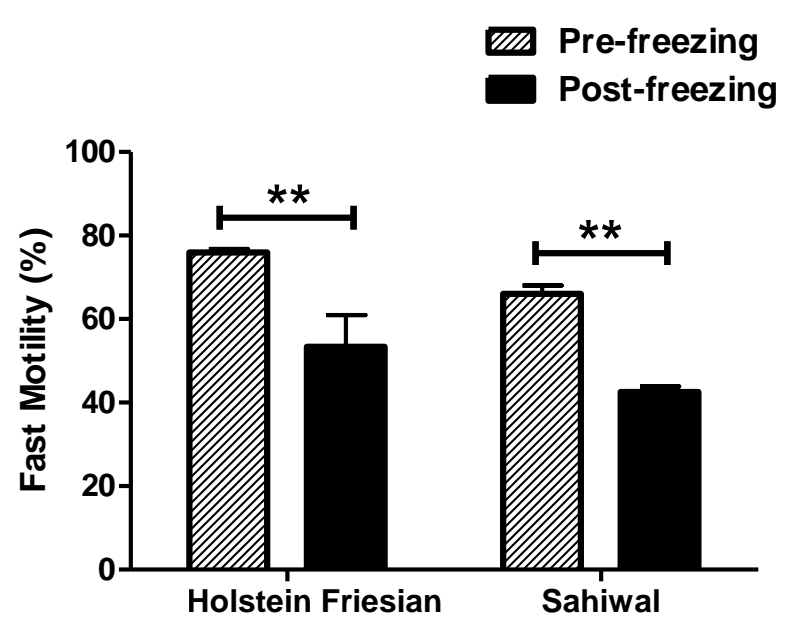

Figure 2. Comparison of pre- and post-freezing fast motility of spermatozoa in pure Holstein Friesian and Sahiwal breeding bull semen. 


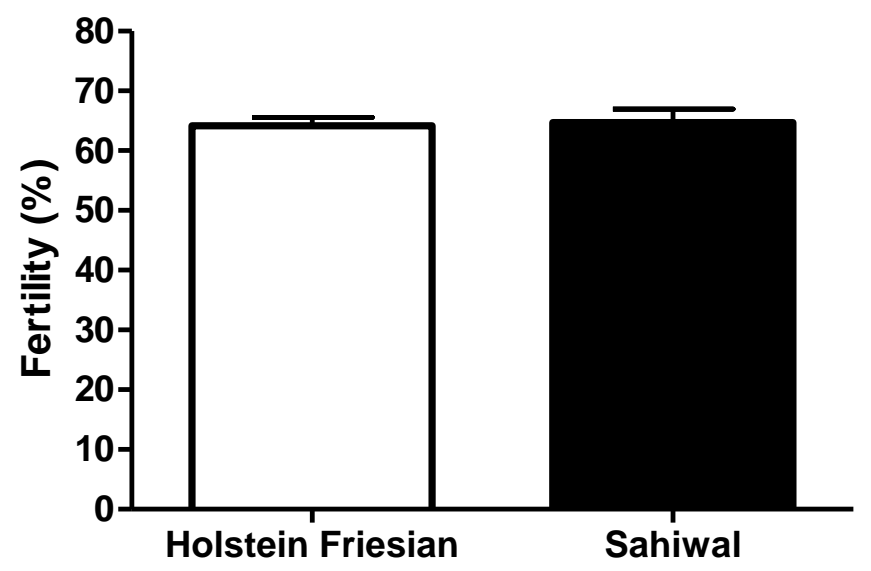

Figure 3. Fertility of pure Holstein Friesian and Sahiwal Breeding bulls using frozen-thawed semen.

\section{Discussion}

\subsection{Evaluation of fresh semen}

Considering the genotypic effect, it was found that the volume of semen varied significantly among the genotypes studied in this study. This observation strongly supports with the findings of the other published works (Brito et al., 2002; Ha et al., 2012). Islam et al. (2018) and Gopinathan et al. (2018) reported 5.63 \pm 0.16 and $4.53 \pm 0.05 \mathrm{ml}$ semen per ejaculation in case of Holstein Friesian which is slightly lower than present study. Baloch et al. (2019) recorded $7.10 \mathrm{ml}$ semen volume in Holstein Friesian which is slightly higher than this study. On the other hand, present findings on the semen volume of Sahiwal breeding bulls strongly support the previous research works (Mostari et al., 2004; Latif et al., 2009). The variation in the ejaculate volume might be attributed to the genetic potentiality of the breeding bulls; scrotal circumference, body size and body weight the secretary activities of the sex glands (Leon et al., 1991; Hafez, 1993). Besides these, semen production also depends on several other factors such as the age, maturity, nutritional status, general health condition, endocrine balance and soundness of the sex organs (Peters, 2002).

The concentration of spermatozoa per $\mathrm{ml}$ semen differed significantly $(\mathrm{p}<0.01)$ between the breeds of breeding bulls. The findings of the present study corroborate with results of other researchers (Hafez, 1983; Hossain et al., 2012; Rahman et al., 2014). According to Debnath (1999), the sperm concentration were $1354 \pm 19.34$ million/ml in Sahiwal and 1204 \pm 19.34 million/ml in Holstein Friesian breeding bulls that are noticeably lower than the present study. According to Ha et al. (2012), the sperm concentration fluctuated between 1.06 to 1.34 billion $/ \mathrm{ml}$ in Holstein Friesian. Ahmed et al. (2014) reported $1528.2 \pm 114.9 \times 10^{6} / \mathrm{ml}$ and $1043.5 \pm 93.2 \times 10^{6} / \mathrm{ml}$ sperm concentration in Sahiwal and Holstein Friesian breeding bulls.

Such variations observed by various workers may be due to difference in age (Ahmad et al., 2003), environment, season (Sardar, 2007), breed, scrotal size, libido, sexual rest, frequency of ejaculation (Kumar, 1979), management, nutrition, physiological status of bulls and genetics (Mathevon et al., 1998).

\subsection{Evaluation of diluted semen}

Motility patterns of diluted semen are very much important to check the semen quality. The research observation is lined with Hoflack et al. (2006) and Galmessa et al. (2014). Islam et al. (2018) found $74.73 \pm 0.76 \%$ progressive motility in Holstein Friesian crossbred breeding bulls which corroborates with the present findings. However, present results are found slightly higher than the results of Morrell et al. (2018); Sundararaman et al. (2012); Rahman et al. (2014) and Hossain et al. (2012) who observed 55.6 $\pm 1.4,65.9 \pm 0.01$, $66.64 \pm 0.50$ and 63.7 to $68.8 \%$ progressive motility, respectively. The fast, slow, local and immotility was 50.06, 7.86, 8.33 and $32.28 \%$ in upgraded Holstein bulls reported by Islam (2015). The reasons of being difference might be due to breed composition, diluter, and evaluation method.

\subsection{Evaluation of frozen semen}

The progressive motility of frozen Sahiwal bull semen reported in this study agrees with the findings of Lecewicz et al. (2015); Dolezalova (2016); Baloch et al. (2019) and Mostari et al. (2004). However, the findings of the present study are lower than the findings of some previous research works (Sugulle et al., 2006; Ansari et al., 2010; Gopinthan et al., 2018) and higher than the findings of Ulfina et al. (2002). The progressive 
motility of Holstein Friesian bull in this study is similar with that of Murphy et al. (2018) and Dias et al. (2018). Conversely, this progressive motility of Friesian bull reported in this study is less than that of CórdovaIzquierdo et al., 2015 and Nasir et al., 2019. This difference might be due to raw semen quality, variation in diluter and freezing method.

\subsection{Comparison of pre- and post-freezing motility of spermatozoa}

Post freezing semen quality in respect of different motility patterns significantly reduced in both Holstein Friesian and Sahiwal breeding bulls. These pre- and post-freezing motility changes are in close agreement with Sonar et al. (2016) in Gir bulls; Pathak (2008) in Sahiwal and Red Sindhi bulls and Jersey $\times$ Red Sindhi bulls (Thakur $e t$ al., 2006). The post freezing motility value in the present study is lower than Jersey bulls (Thakur $e t$ al., 2006) while higher as compared to Friesian bulls (Mandal and Tyagi, 2007) and HF $\times$ Jersey $\times$ Kankrej bulls (Raval et al., 2007). Bhupal et al. (1993) reported that in identical environment, HF bull semen had better post freezing motility than that of Sahiwal bulls. Post-freezing motility can be affected by dilutors (Belorkar $e t$ al., 1993; Pramanik and Raina, 1998), method used for glycerol addition (Gilbert and Almquist, 1978; Arancibia et al., 1987) and equilibration time (Belorkar et al., 1993). All these factors might have contribution to the difference in observations by other workers for post thaw motility.

\subsection{Fertility of breeding bulls}

The findings of the present study is lined with Islam et al. (2018) who reported $63.67 \pm 1.46 \%$ non-return rate in Holstein Friesian crossbred breeding bulls. Moreover, the present findings coincide with the findings of other researchers (Nasrin et al., 2008; Rahman et al., 2014). Mostari et al. (2004) found $70.90 \pm 0.35 \%$ that is slightly higher than this study. Difference in fertility might be due to genetic makeup of cows and bulls, semen processing, thawing of straw-prior to insemination, number of inseminations, quality of semen, site of semen deposition, proper timing of insemination and reproductive health of the female.

\section{Conclusions}

This study reveals that frozen semen quality in terms of different motility patterns of Holstein Friesian is better than that of Sahiwal breeding bulls but fertility of both breeds are similar in field condition. Therefore, frozen semen of both breeds can be used in field level for the genetic improvement of cattle. In addition, these results have given an insight view to the farmers, researchers, policy makers and entrepreneurs about the frozen semen quality and fertility of imported pure Holstein Frisian and Sahiwal breeding bulls at field condition in Bangladesh.

\section{Acknowledgements}

The authors are grateful to the Department of Animal Breeding and Genetics, Bangladesh Agricultural University, Mymensingh for logistic support, American Dairy Limited (ADL) for providing research facilities and Ministry of Science and Technology for providing the financial support.

\section{Conflict of interest}

None to declare.

\section{References}

Ahmad M, MT Asmat, NU Rehman and MZ Khan, 2003. Semen characteristics of Sahiwal bulls in relation to age and season. Pak. Vet. J., 23: 202-06.

Ahmed KU, MR Islam, MKU Talukder, Z Rahman, MM Hossain and MMU Bhuiyan, 2014. Influence of breed, age and collection interval on semen quality of AI dairy bulls in Bangladesh. Bang. Res. Publ. J., 10: 275282.

Ahmed Z and TS Islam, 1987. Cattle breeding programme through artificial insemination in Bangladesh, Central Cattle Breeding Station, Savar, Dhaka, Bangladesh. pp. 61-62.

Ansari MS, BA Rakha, SMH Andrabi, N Ullah and S Akhter, 2010. Cryopreservation of Sahiwal bull epididymal spermatozoa. Pakistan J. Zool., 42: 741-743.

Arancibia EA, WA Hube, MC Jara and OC Veer, 1987. Effect of sudden temperature changes in thawed semen on the percentage of sperm motility and spermatozoa with normal acrosome in mini tubes. Anim. Breed. Abstract 55: 2797. 
Baloch AH, HK Kunbhar, MI Memon, SM Sharif, RA Leghari and ZI Rajput, 2019. Fresh and post thaw quality characteristics of Holstein Friesian bull semen maintained at semen production unit Quetta Balochistan, Pakistan. P. App. Biol., 8: 780-789.

BBS, 2019. Bangladesh Bureau of Statistics. Statistical Year Book of Bangladesh, Statistics Division, Ministry of Planning, Government of Peoples Republic of Bangladesh.

Belorkar PM, AJ Dhami and SB Kodagali, 1993. Effect of season and extenders onfreezability, GOT release and fertility of crossbred bull's semen. 46: 198-202.

Bhupal S, G Mohan and KL Sahni, 1993. A comparative study on the freezability of semen of cattle (native and exotic) and buffaloes. Indian J. Anim. Sci., 63: 1172-73.

Brito LFC, AEDF Silva, LH Rodrigues, FV Vieira, LAG Deragon and JP Kastelic, 2002, Effect of environmental factors, age, and genotype on sperm production and semen quality in Bos indicus and Bos Taurus in Brazil. Animl Repro. Sci., 70: 181-190.

Contria A, C Valorzb, M Faustinic, L Wegherb and A Carluccioa, 2010. Effect of semen preparation on casa motility results in cryopreserved bull spermatozoa. Theriogenology, 74: $424-435$

Córdova-Izquierdo A, G Ruiz-Lang, R Espinosa-Cervantes, AE Iglesias-Reyes, M Méndez-Mendoza, R HuertaCrispín, AE Villa-Mancera, MDL Juárez-Mosqueda, P Sánchez-Aparicio, J Olivares-Pérez, JE Guerra-Liera and G Cansino-Arroyo, 2015. Sperm quality in Holstein bulls Friesian and Brahmans of frozen semen commercially. Open J. Anim. Sci., 5: 229-231.

Debnath C, 1999. Study of characteristics and measurements of spermatozoa in different breeds of cattle and goat, MS thesis, Department of Animal Breeding and Genetics, Bangladesh Agricultural University, Bangladesh. pp. 40.

Dias EAR, SP Campanholi, GF Rossi, C de Paula Freitas Dell'Aqua, JA Dell'Aqua, FO Papa, MF Zorzetto, CCP de Paz, LZ Oliveira, MEZ Mercadante and FM Monteiro, 2018. Evaluation of cooling and freezing systems of bovine semen. Anim. Reprod. Sci., 195: 102-111.

Dolezalova M, LS tadnik, Z Biniova and R Stupka, 2016. Equilibration and freezing interactions affecting bull sperm characteristics after thawing. Czech J. Anim. Sci., 61: 515-525.

Foote RH, 1972. How to measure sperm cell concentration by Turbidity (Optical Density). In: proceedings of the $4^{\text {th }}$ technical conference artificial insemination and reproduction, 1972, Milwaukee, WI. Columbia, MO: NAAB. pp. 57-61.

Galmessa U, TK Mohanty, VS Raina, AK Gupta and S Prasad, 2014. Post-thawed and fresh spermatozoa motion characteristics of Sahiwal bulls under Computer Assisted Semen Analyser. Int. J. Livest. Prod., 5: 6570.

Gilbert and JO Almquist, 1978. Effects of processing procedure on post thaw acrosome retention and motility of bovine spermatozoa packed in $0.3 \mathrm{ml}$ straw at room temperature. J. Anim. Sci., 46: 225-31.

Gopinathan A, SN Sivaselvam, k Kulasekar and JJ Kirubaharan, 2018. Effect of non-genetic factors on semen quality traits of crossbred Holstein Friesian bulls in organized farming condition. Int. J. Curr. Microbiol. App. Sci., 7: 3219-3229.

Ha MT, NH Sac, LB Que, PT Hai, HM Tuan, PV Tiem, NTT Hoa, Kiem PV and LV Thong, 2012. Relationship between scrotal circumferences with some Indicators of semen parameters in Holstein Friesian and Brahman Breeding bulls, Vietnam Ruminant Breeding Center. Livest. Res. Rural., 24.

Hafez ESE, 1993. Reproduction in Farm Animals, 6th Edition, Lea \& Fibiger, Philadelphia, pp. 405-429.

Hoflack G, G Opsomer, A Van Soom, D Maes, A de Kruif and L Duchateau, 2006. Comparison of sperm quality of Belgian Blue and Holstein Friesian bulls. Theriogenology, 66: 1834-1846.

Hossain H, MM Khatun, MM Islam and OF Miazi, 2012. Semen characteristics of breeding bulls at the Central Cattle Breeding and Dairy Farm of Bangladesh. Bang. J. Anim. Sci., 41: 1-5.

Hossain MM, AKFH Bhuiyan, MO Faruque and GK Deb, 2006. Characterization and distribution pattern of Red Chittagong Cattle of Bangladesh. Progress. agric., 17: 103-110.

Islam MM, AS Apu, SAM Hoque, MY Ali and S Karmaker, 2018. Comparative study on the libido, semen quality and fertility of Brahman cross, Holstein Friesian cross and Red Chittagong breeding bulls. Bang. J. Anim. Sci., 47: 61-67.

Islam MR, 2015. evaluation of semen parameters of Brahman cross, Holstein cross and Local bulls using NearInfrared Spectroscopy. MS thesis, Department of Animal Breeding and Genetics, Bangladesh Agricultural University, Bangladesh. pp. 36.

Kumar S, 1979. Effect of successive ejaculations on cytomorphology and biochemistry of bull and buffalo semen. MVSc thesis, G. B. Pant University of Agriculture and Technology, Pantnagar. 
Latif MA, JU Ahmed, MMU Bhuiyan and M Shamsuddin, 2009. Relationship between Scrotal Circumference and Semen Parameters in Crossbred Bulls, Department of Surgery and Obstetrics, Faculty of Veterinary Science, Bangladesh Agricultural University, Mymensingh-2202, Bangladesh. Bangladesh Veterinarian, 26: $61-67$.

Lecewicz M, D Herring, S Kaminski, A Majewska and W Kordan, 2015. Selected qualitative and biochemical parameters of cryopreserved semen of Holstein-Friesian (HF) AI bulls. Pol. J. Vet. Sci., 18: 237-239.

Leon H, AA Porras and CS Galina, 1991. Effect of the collection method on semen characteristics of Zebu and European Type cattle in the tropics, Theriogenology, 36: 349-355.

Mandal DK and S Tyagi, 2007. Cyto-morphological abnormalities and cell membrane integrity of frozen thawed spermatozoa of Frieswal bulls and their relationship with fertility. Indian J. Anim. Reprod., 28: 3033.

Mathevon M, MM Buhr and JC Dekkers, 1998. Environmental, management, and genetic factors affecting semen production in Holstein bulls. J. Dairy Sci., 81: 3321-30.

Morrell JM, AS Valeanu, N Lundeheim and A Johannisson, 2018. Sperm quality in frozen beef and dairy bull semen. Acta Vet. Scand., 60: 1-10.

Mostari MP, MGM Rahman, MAMY Khandoker and SS Husain, 2004. Evaluation of bulls based on semen quality and herd fertility. Pakistan J. Biol. Sci., 7: 2177-2181.

Murphy EM, CO Meara, B Eivers, P Lonergan and S Fair, 2018. Optimizing storage temperature of liquid bovine semen diluted in INRA96. J. Dairy Sci., 101: 5549-5558.

Nasir SE, AS Elsheikh and SEA Makawi, 2019. Fertility of Friesian bull's semen diluted with low fat cow milk. J. Agric. Vet. Sci., 12: 62-66.

Nasrin S, MR Amin and MK Alam, 2008. Evaluation of semen and non-return rate of bulls in artificial insemination center. Bang. J. Anim. Sci., 37: 1-7.

Pathak V, 2008. Studies on seminal characteristics and freezability of Sahiwal and Red Sindhi bull. MVSc thesis submitted to Indira Gandhi Krishi Viswavidyalaya, Raipur.

Peters, 2002. Evaluation of Goat Populations in Tropical and Subtropical Environments. http://kinne.net/fertbuck.htm

Pramanik PS and VS Raina, 1998. Refrigerator preservation of buffalo semen in various extender. Indian J. Dairy Sci., 51: 375-79.

Rahman MA, NS Juyena, JU Ahmed, RN Ferdousy, S Chakma, MZ Rine and AMM Tarif, 2014. Evaluation of semen for breeding soundness of four different breeds of bull used for artificial insemination. J. Agric. Vet. Sci., 7: 28-34.

Raval RJ, AJ Dhami and FS Kavani, 2007. Effect of extender additives on motility, viability and acrosomal integrity of triple bred $(\mathrm{HF} \times \mathrm{J} \times \mathrm{K})$ bulls's spermatozoa during cryopreservation. Indian J. Anim. Reprod., 2: $7-15$.

Salisbury MW, NL Van Denmark and IR Lodge, 1978. Physiology of reproduction and artificial insemination in cattle, $2^{\text {nd }}$ edition, Freeman and company, San Francisco, USA. pp. 385-399.

Sardar MJU, 2007. Environment related variation in the semen characteristics of bulls used for artificial insemination (AI) programme in Bangladesh. Univ. J. Zool., Rajshahi Univ., 26: 81-88.

Sarder MJU, MsR Sultana, L Nahar and MA Islam 2007. Phenotypic characteristics of individual bull used for artificial insemination (AI) programme in Bangladesh. J. Bio-Sci., 15: 99-109.

SAS, 2009. Statistical Analysis System, Computer Software, Version 9.1.3: Statistics SAS Institute Inc. Cary, NC 27513, NC27513, USA.

Sonar BP, RP Tiwari, MR Poyam, GK Mishra, AK Pandey, AK Nair and SA Sahasrabudhe, 2016. Characteristics and freezability of Gir bull semen. Indian J. Anim. Sci., 86: 264-272.

Sudano MJ, AM Crespilho, CB Fernandes, A Martins Junior, FO Papa, J Rodrigues, R Machado and FC Landim-Alvarenga, 2011. Use of Bayesian inference to correlate in vitro embryo production and in vivo fertility in Zebu bulls. Vet. Med. Int., pp. 1-6.

Sugulle AH, MMU Bhuiyan and M Shamsuddin, 2006. Breeding soundness of bulls and the quality of their frozen semen used in cattle artificial insemination in Bangladesh. Livest. Res. Rural., 18.

Sundararaman MN, J Kalatharan and KTP Jawahar, 2012. Computer assisted semen analysis for quantification of motion characteristics of bull sperm during cryopreservation cycle. Vet. World, 5: 723-726.

Thakur S, M Singh and NK Vasishta, 2006. Studies on the semen quality of different Veterinary Institutions. Indian J. Anim. Reprod., 27: 59-61.

Ulfina G, and VS Raina, 2002. Effect of age and scrotal circumference on seminal attributes in dairy bulls. Indian J. Anim. Sci., 72: 1114-1116. 